\title{
Sosialisasi Pencegahan Penyebaran Virus Corona Melalui Video Edukasi : Peran Mahasiswa Sastra Inggris Unkhair Dalam Mengahadapi New Normal
}

\author{
Sulmi Magfirah ${ }^{1}$ \\ sulmi@unkhair.ac.id ${ }^{1}$ \\ ${ }^{1}$ Universitas Khairun
}

\section{Article History:}

Received: 27-11-2020

Accepted: 28-01-2021

Keywords : Corona Virus, Educational Video, New Normal, Socialization

\begin{abstract}
:
Socialization of the prevention of the Corona virus through videos in the New Normal era aims (1) to provide the information to the public and knowledge about preventing the spread of the Corona virus, starting from wearing mask, washing hands, social distance, safe from Corona virus transmission, maintaining immunity and (2)to provide an education to the society in preventing the spread of the Corona virus in the New Normal era. In producing the video itself, it was carried out several stages, including; making a timeline for socialization activities and a video script. The next step is taking videos such as; Taking Videos of some students who will do the socialization, taking videos to appeal the prevention of COVID-19 in the New Normal era by the Head of English Literature Study Program at the Faculty of Cultural Sciences. The next is video editing, which will be merging and editing the videos that have been taken. The last is publishing through several social media, including Facebook, Instagram and Whatsapp and on DVD for internal production of the Faculty of Cultural Sciences Khairun University.
\end{abstract}

\section{Pendahuluan}

Pemerintah Provinsi Maluku Utara saat ini masih terus memaksimalkan usaha penanganan dan pencegahan dari berbagai sektor pemerintahan demi melawan COVID-19. Pemerintah bersama dengan tim gugus tugas Maluku Utara setiap harinya mengumumkan tambahan pasien positif COVID-19 dan tersebar di berbagai media. Tambahan pasien positif itu didapatkan setelah memeriksa sejumlah spesimen menggunakan metode swab di Rumah Sakit Siloam Manado dan RSUD Chasan Boesorie. Pengumuman tersebut menyajikan pula data Orang Tanpa Gejala (OTG), Orang dalam Pemantauan (ODP), Pasien dalam Pengawasan (PDP), pasien sembuh, dan meninggal dunia.

Usaha penanganan dan pencegahan terus dilakukan demi melawan COVID-19 dengan gejala mirip flu. Kasus virus Corona diketahui melalui penyakit misterius yang melumpuhkan Kota Wuhan, China. Tragedi pada akhir 2019 tersebut terus berlanjut hingga penyebaran virus Corona mewabah ke seluruh dunia. Indonesia, khususnya Maluku Utara, masih bergelut melawan virus Corona hingga saat ini, sama dengan daerah lain di seluruh 
Indonesia.

World Health Organization (WHO) memberi nama virus baru tersebut Severe acute respiratory syndrome Corona virus - 2 (SARS-CoV-2) dan nama penyakitnya sebagai Corona virus disease 2019 (COVID-19) (WHO, 2020). Dalam pernyataan keilmuan oleh WHO (2020), terdapat 4 macam transmisi SARS-CoV-2 sebagai implikasi terhadap kewaspadaan pencegahan infeksi, diantaranya; (a) transmisi kontak dan droplet, (b) Transmisi Melalui Udara, (c) Transmisi Fomit, (d) dan Moda-moda Transmisi Lain. Pernyataan keilmuan ini sebagai bentuk pengendalian pencegahan penyakit yang umumnya menyebar dari orang ke orang, serta pengendalian infeksi untuk memutus rantai transmisi.

Masyarakat Indonesia sebagai salah satu negara terdampak Corona harus melakukan upaya pencegahan penyebaran, yaitu dengan social distancing dan isolasi diri (Mona, 2020), karena kita tidak kuasa menghentikan virus Corona, maka yang dapat dilakukan adalah mencegah penyebaran lebih luas. Dari beberapa penelitian yang ada, termasuk oleh Larasati dan Haribowo (2020) mengatakan bahwa efektif penggunaan antiseptik dan disinfektan untuk membunuh virus, namun jika tidak diikuti dengan pembatasan jarak antara penderita maupun pembawa, maka tetap saja penularan akan semakin banyak dan tidak bisa di hindari. Oleh karena itu, perilaku individu dan aturan umum kebersihan pribadi sangat penting untuk mengendalikan penyebaran virus Corona ini.

Walaupun demikian, masyarakat memerlukan aktifitas diluar rumah dan berkegiatan demi memenuhi kebutuhan ekonomi keluarga. Normal baru adalah cara hidup atau cara baru dalam menjalankan aktifitas hidup ditengah pandemik COVID-19 yang belum usai. Menurut Sigit tentang normal baru (Habibi, 2020), menerangkan bahwa normal baru dibutuhkan untuk menyelesaikan masalah kehidupan selama COVID-19. Hal ini sebagai alternatif sebagai dasar kebijakan nasional untuk memenuhi konsumsi, selain itu juga kondisi sosial juga membutuhkan interaksi.

Saat ini, Presiden Joko Widodo telah memberlakukan New Normal atau kenormalan baru di sejumlah daerah termasuk Maluku Utara. Sehingga, Pemerintah Provinsi (Pemprov) Maluku Utara (Malut) mengusulkan 5 kabupaten ke pemerintah pusat untuk memulai New Normal di tengah pandemi COVID-19. Sekretaris Daerah Samsuddin A Kadir menyebutkan pengusulan 5 daerah tersebut karena daerah-daerah tersebut memiliki angka penyebaran COVID-19 yang rendah. "Bahkan ada kabupaten yang hingga saat ini belum ada kasus posif COVID-19," kata Samsuddin dalam media Indonesia.

Berbagai upaya pencegahan penyebaran virus Corona sudah banyak dilakukan baik https://journal.universitasbumigora.ac.id/index.php/ADMA 
oleh pemerintah maupun sektor swasta pasca pandemi. Seluruh masyarakat pun ikut berpartisipasi dalam membantu sesamanya yang mengalami keterpurukan ekonomi pada masa pandemi ini. Sebagai upaya partisipasi penanganan pencegahan virus Corona ini, Program Studi Sastra Inggris FIB Universitas Khairun merasa terpanggil untuk ikut berpartisipasi pada sosialisasi pencegahan penyebaran Virus Corona di era New Normal. Sosialisasi ini akan dilakukan dalam bentuk pembuatan Video edukasi dengan Judul : Peran Mahasiswa Sastra Inggris Unkhair dalam Menghadapi New Normal. Luaran yang dihasilkan dalam sosialisasi ini adalah video edukasi yang disebar melalui media sosial oleh dosen dan mahasiswa Program Studi Sastra Inggris Unkhair serta bentuk produksi DVD.

\section{Metode}

Pembuatan video edukasi pencegahan penyebaran virus Corona di era New Normal secara umum ditujukan pada seluruh masyarakat di provinsi Maluku Utara untuk lebih memahami dan mendapatkan informasi yang benar tentang bagaimana pencegahan penyebaran virus Corona di era New Normal dan secara khusus ditujukan para mahasiswa Program Studi Sastra Inggris Fakultas IImu Budaya untuk dapat memahami bagaimana menjadi aktor penting dalam pencegahan penyebaran virus Corona, membuat suatu video edukasi, serta bagaimana melakukan editing video tersebut.

Pembuatan video edukasi pencegahan penyebaran virus Corona di New Normal ini bertujuan untuk memberikan informasi yang benar kepada masyarakat dan pengetahuan tentang pencegahan penyebaran virus Corona pasca pandemik di Era New Normal mulai dari penggunaan masker, mencuci tangan, pembatasan sosial, jarak aman penularan virus Corona, menjaga imunitas agar kebal terhadapa virus Corona dan bagaimana peran mahasiswa untuk memberikan penyuluhan kepada masyarakat tentang cara-cara pencegahan penyebaran virus Corona tersebut di atas melalui video edukasi.

Target dari pengabdian kepada masyarakat oleh mahasiswa program studi Sastra Inggris Unkhair dalam pembuatan video edukasi pencegahan penyebaran virus Corona ini adalah memberikan pemahaman dan informasi yang benar kepada masyarakat tentang bagaimana cara mencegah penyebaran virus Corona pasca pandemik di era New Normal. Selain itu juga untuk mengikuti protokol kesehatan sesuai aturan pemerintah pusat antara lain mencuci tangan dengan benar, penggunaan masker saat keluar rumah dan saat beraktifitas, mengurangi aktifitas luar rumah jika tidak penting, jaga jarak aman agar tidak tertular virus Corona. Tujuan tambahan lainnya yaitu untuk meningkatkan partisipasi Mahasiswa sebagai garda terdepan untuk melakukan edukasi dan penyuluhan kepada masyarakat tentang pencegahan virus Corona di era New Normal.

Sebelum melakukan pengambilan Video edukasi, Tim pelaksana melakukan meeting 
terlebih dahulu untuk mendesain alur skrip video yang akan dibuat. Hasil diskusi tim memutuskan akan menampilkan Kaprodi Sastra Inggris dan mahasiswa Sastra Inggris. Peran utama video ini untuk memberikan edukasi mengenai hal-hal terkait pencegahan penyebaran virus Corona dan 5 orang mahasiswa sebagai aktor pendukung. Opening Video akan ditampilkan berita-berita media terkait perkembangan virus Corona di Indonesia, WHO dan video lokasi Fakultas IImu Budaya Universitas Khairun.

\section{Pembahasan}

Kegiatan pengabdian kepada masyarakat dalam bentuk video edukasi yang diperankan oleh mahasiswa Sastra Inggris Unkhair dilakukan dengan persiapan serius dan waktu yang cukup Panjang. Hal ini di karena adanya penerapan social distancing dalam lingkup kampus Univesitas Khairun. Persiapan ini dilakukan selain pengurusan izin administrasi dan sosialisasi, juga mempersiapkan tim mahasiswa yang akan memerankan kegiatan sosialisasi dalam menyukseskan kegiatan. Sebanyak 5 mahasiswa program studi Sastra Inggris disiapkan dengan pembagian tugas masing-masing. Tim juga mempersiapkan narasumber untuk memberikan penyuluhan tentang pencegahan virus Corona di era New Normal khususnya di lingkungan program studi Sastra Inggris Unkhair.

Sebelum melakukan pengambilan video, tim pelaksana pengabdian melakukan diskusi terlebih dahulu terkait susunan kegiatan yang akan dilakukan selama pengambilan video berlangsung. Tujuannya adalah untuk mempermudah jalannya kegiatan serta membuat pelaksanaan kegiatan terstruktur dan terarah. Setelah memperoleh kesepakatan dari diskusi mengenai rundown kegiatan, tim kemudian membagi tugas masing-masing dan menjalankan peran dalam video edukasi ini. Peran mahasiswa ini sangat menunjang dalam mensukseskan pembuatan sosialisasi video edukasi oleh mahasiswa Sastra Inggris Unkhair.

Tahap selanjutnya yaitu pembuatan naskah sosialisasi video edukasi. Sebelum melakukan pengambilan video, tim terlebih dahulu membuat naskah atau alur cerita video yang akan dibuat. Hasil diskusi kemudian memutuskan akan menampilkan ketua program studi Sastra Inggris dan 5 orang mahasiswa Sastra Inggris sebagai pemeran utama dalam sosialisasi video edukasi pencegahan virus Corona di era New Normal. Opening video akan menampilkan himbauan oleh presiden republik Indonesia tentang menghadapi virus Corona di Indonesia yang masih berlanjut, serta pengambilan gambar beberapa lokasi di Fakultas IImu Budaya Universitas Khairun.

Tahapan selanjutnya yaitu tahapan pengambilan video edukasi. Pada tahapan ini, tim terlebih dahulu memastikan lokasi aman untuk melakukan take video dan juga memastikan cuaca yang mendukung kegiatan sosialisasi video edukasi. Adapun beberapa 
tahapan pengambilan scene video, sebagai berikut:

a. Pengambilan video lokasi rumah pemain pendukung oleh mahasiswa Sastra Inggris.

b. Pengambilan video lokasi Fakultas Ilmu Budaya Unkhair.

c. Pengambilan video beberapa mahasiswa pendukung yang memberikan video edukasi kepada masyarakat.

d. Pengambilan video himbauan pencegahan virus Corona oleh Kepala Program Studi Sastra Inggris.

e. Pengambilan video oleh mahasiswa Sastra Inggris dalam sosialisasi pencegahan virus Corona di era New Normal.

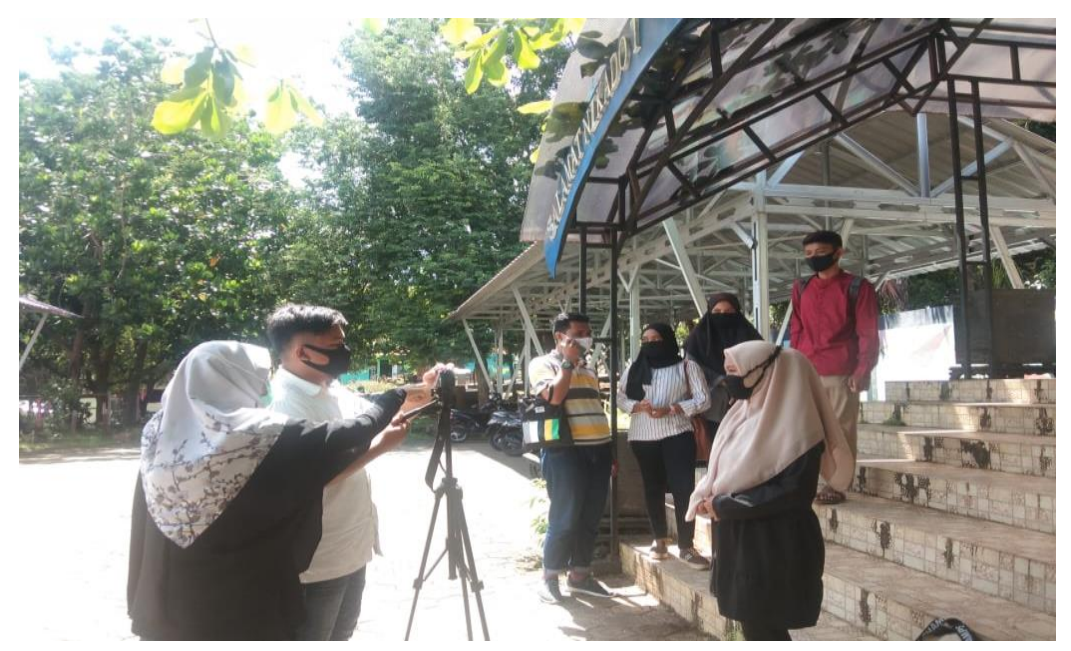

Gambar 2. Proses take video oleh mahasiswa Sastra Inggris Unkhair.

Setelah seluruh scene diambil, maka tahapan selanjutnya adalah video editing. Adapun software yang digunakan dalam melakukan penggabungan dan pemotongan video yang sesuai dengan topik sosialisasi adalah software Adobe Premiere, yang berdurasi 7 menit 21 detik. Selain sosialisai oleh mahasiswa Sastra Inggris Unkhair, juga terdapat himbauan tentang bahaya virus Corona oleh penggalan video Presiden RI dan himbauan WHO (World Health Organization). Tujuannya yaitu untuk lebih memperkuat pemahaman tentang pencegahan virus Corona di era New Normal dalam kegiatan sosialisasi video edukasi ini kepada mahasiswa program studi Sastra Inggris dan kepada masyarakat kota Ternate Maluku Utara.

Tahapan terakhir dalam pembuatan video edukasi ini adalah sosialisasi video edukasi oleh mahasiswa Sastra Inggris Unkhair yang telah selesai di edit. Setelah itu video disebarkan melalui media sosial seperti youtube Sastra Inggris Unkhair https://youtu.be/AVzf1-Vaeel. Pada Facebook Sastra Inggris Unkhair yaitu melalui https://l.facebook.com/l.php?u=https $\% 3 \mathrm{~A} \% 2 \mathrm{~F} \%$ sedangkan penyebaran melalui sosial media oleh dosen pelaksana dan masing-masing mahasiswa pemeran pendukung. 


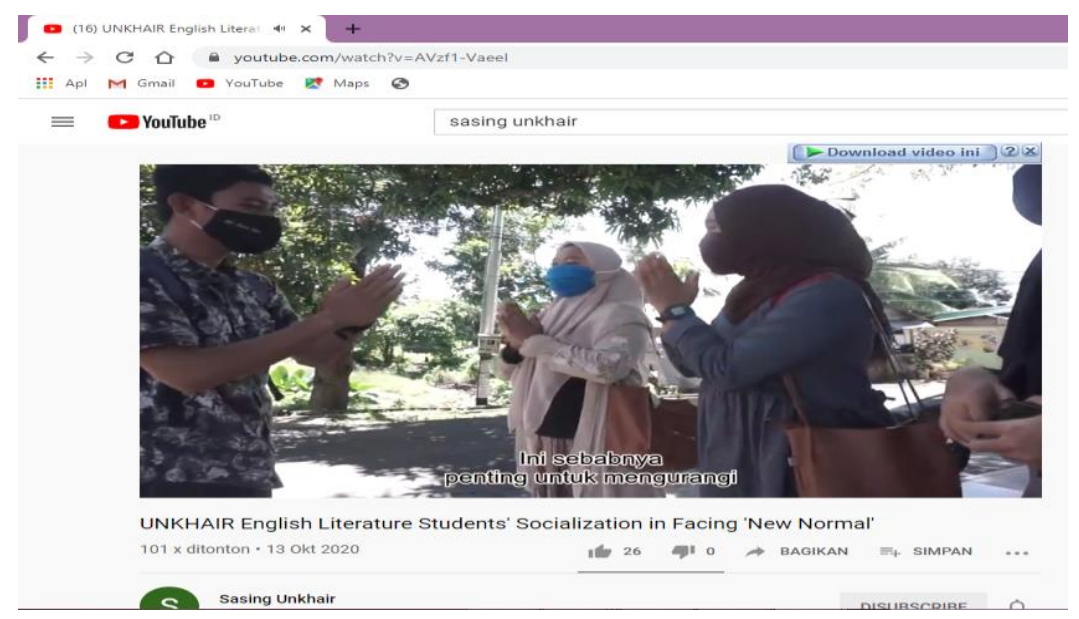

Gambar 2. Tampilan youtube sosialisasi video edukasi "New Normal" oleh mahasiswa Sastra Inggris Universitas Khairun

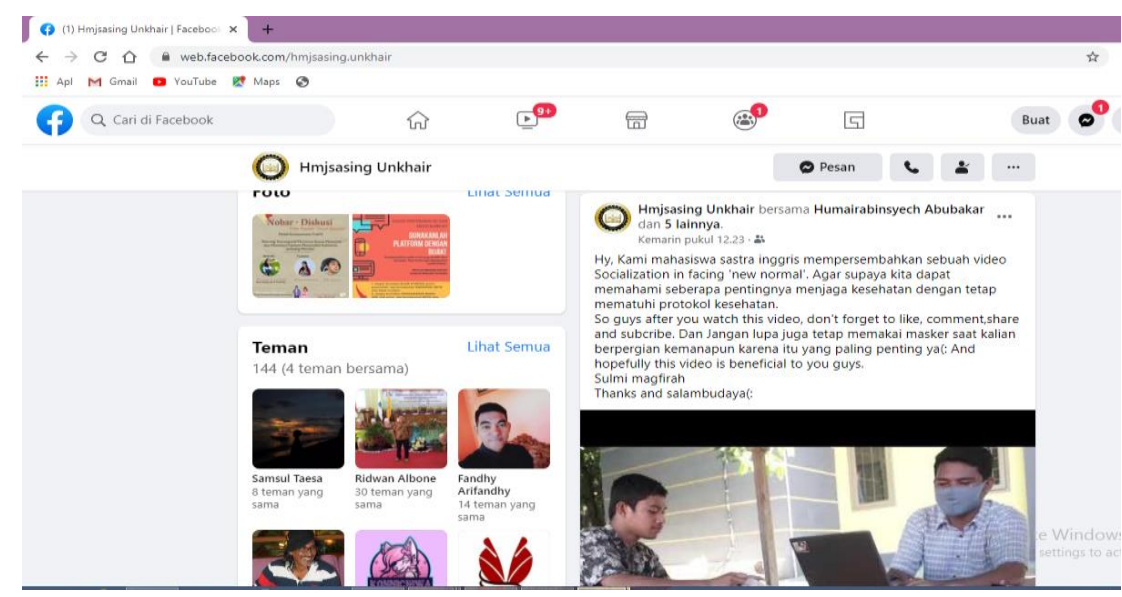

Gambar 3. Tampilan facebook sosialisasi video edukasi 'New Normal' oleh mahasiswa Sastra Inggris Universitas Khairun

\section{Kesimpulan}

Kegiatan sosialisasi video edukasi pencegahan virus Corona di era New Normal oleh mahasiswa Sastra Inggris Unkhair telah selesai dilakukan dan telah disebar melalui sosial media seperti youtube dan facebook, dengan melibatkan pimpinan program studi Sastra Inggris Fakultas IImu Budaya Unkhair. Video tersebut dapat diakses melalui link akses https://youtu.be/AVzf1-Vaeel dan juga telah tersebar melalui beberapa social media dosen dan mahasiswa. Sosialisasi video edukasi ini berisi anjuran dan himbauan tentang cara-cara pencegahan virus Corona di era New Normal, antara lain: mencuci tangan, memakai masker dengan teratur, menjaga jarak, menggunakan hand-sanitizer, serta anjuran dirumah saja jika aktifitas luar rumah tidak begitu penting.

Sosialisasi pencegahan virus Corona melalui video edukasi dirasakan sangatlah penting apabila keterlibatan beberapa dosen dan lebih banyak mahasiswa pendukung. Akan 
tetapi karena adanya keterbatasan tim pelaksana dikarenakan kondisi dan situasi kampus yang menghimbau untuk menghindari perkumpulan, sehingga membatasi gerak tim pelaksana kegiatan. Oleh karena itu, sosialisasi melalui video edukasi yang melibatkan beberapa pihak merupakan langkah tepat dalam menyebarluaskan manfaat untuk menjangkau masyarakat yang lebih luas, bukan hanya menjangkau lingkup Universitas Khairun, tetapi juga masyarakat kota Ternate Maluku Utara .

\section{Ucapan Terima Kasih}

Penulis Mengucapkan terima kasih kepada Program Studi Sastra Inggris Fakultas IImu Budaya Universitas Khairun yang turut terlibat secara langsung dalam pelaksanaan sosialisasi video edukasi di lingkungan Fakultas IImu budaya. Selain itu terima kasih juga diucapkan kepada mahasiswa pemeran pendukung sehingga pelaksanaan pengabdian kepada masyarakat ini dapat berjalan dengan baik. Meskipun situasi dan kondisi pandemi saat ini, akan tetapi kegiatan sosialisasi ini juga sebagai bentuk turut serta dalam pencegahan dan penanganan virus Corona, dalam membantu pemerintah provinsi Maluku Utara untuk mengurangi dampak penyebaran COVID-19.

\section{Daftar Pustaka}

Cheppy Riyana. 2007. Pedoman Pengembangan Media Video. Jakarta: P3AI UPI.

Habibi, Andriani. 2020. Normal Baru Pasca Covid 19. ADALAH Buletin Hukum dan Keadilan : 197 204.

Larasati, Annisa Lazuardi dan Haribowo Chandra. 2020. Penggunaan Desinfektan dan Antiseptik pada Pencegahan Penularan COVID-19di Masyarakat. Majalah Farmasetika : 137 -145.

Mona, Nailul. 2020. Konsep Isolasi dalam Jaringan Sosial untuk Meminimalisasi Efek Contagious (Kasus Penyebaran Virus Corona di Indonesia). Jurnal Sosial Humaniora Terapan : 117125.

Nurdyansyah dan Fahyuni, Eni Fahriyatu. 2016. Inovasi Model Pembelajaran. Sidorajo : Nizamia Learning Center.

WHO.2020.WHO Director-General's remarks at the media briefing on 2019-nCov on February 2020. Cited September $12^{\text {th }}$ 2020. Available https://www.who.int/dg/speeches/detail/who-directorgenerals-remarks-at-the -media-briefing-on-2019-ncov-on-11-february-2020. (Diakses pada tanggal 12 September 2020).

Yuliana. 2020. Corona Virus Disease : Sebuah Tinjauan Literature. Wellness and Healthy Magazine. P. 187-192

[PK] Pernyataan Keilmuan WHO. 2020. Transmisi SARS-CoV-2 : implikasi terhadap kewaspadaan pencegahan infeksi (Diakses pada tanggal 09 Juli 2020).

Kasus Virus Corona (Covid 19) Maluku Utara, www.malutpost.com (Diakses pada tanggal: 22 Mei, 2020)

CNN Indonesia. 2020. Presiden Imbau Untuk Bersatu Menghadapi Virus Corona [Internet].(Diunduh pada tanggal 02/10/20020). Tersedia pada https://www.youtube.com/watch?v=QUaa EFQZcM. 
Teacher Mel. 2020. WHO Present Demonstration on How to Wear Mask Properly [Internet]. (diunduh pada tanggal 03/10/20020). Tersedia pada https://www.youtube.com/watch?v=Q7E4GEs4S90.

World Health Organization (WHO). 2020. Dr Mike Ryan - "Every person needs to look at their COVID19 risk." [Internet]. (Diunduh pada tanggal 05/10/20020). Tersedia pada https://www.youtube.com/watch?v=ddefs 